\title{
The Effectiveness Of Self-Control Training To Improve The Dicipline Of Female Students
}

\author{
Nurmala Rimadhani \\ Master of Psychology University of Gunadarma \\ Margonda Raya Street No. 100, Depok 16424 \\ nurmalarmdhn@gmail.com
}

\begin{abstract}
Adolescence is a period of transition from childhood to adulthood. During this period, adolescents will experience various changes in their lives and are at risk of experiencing various problems. These characteristics of teenagers make them need self-control training. In this study, the sample of teenagers who were taken were high school students who were in the dormitory. This study aims to examine the effectiveness of self-control training to improve discipline in female students conducted at the L High School (SMA) in the city of Depok, West Java. The results showed that there was a difference of 0.001 (sig. > 0.01) which was carried out with the t-test. These results show that self-control training is very influential on increasing female students' self-control while in school dormitories.
\end{abstract}

Keywords: adolescence, school dormitories, self-control.

\section{INTRODUCTION}

School is an institution or building as a place to learn and teach, as well as a place to receive and give lessons, school is also a place of education for children which aims to teach children to be able to advance the nation later. The schools that are required in Indonesia today are Elementary School (SD), Junior High School (SMP), and Senior High School (SMA). SMA is a formal basic education that is carried out over a period of three years, starting from grade 10 to grade 12 . There are various kinds of education systems implemented in schools today. One of them is the education system in schools that requires students to live in school dormitories.

The main purpose of boarding-based schools is to instill discipline in students. According to Djamarah (in Afiati, 2018) a disciplined attitude can make a person feel obedient and obedient to the values that are believed to be more responsible for being able to regulate the order of personal and group life. This is also supported by Sochib's statement (in Afiati, 2018) which states that with a disciplined attitude it is hoped that it can make students have a regular lifestyle based on religious values, cultural values, social rules, views of life, and a meaningful life attitude for themselves. . However, in reality there are still students who do not obey the rules and commit various violations in schools and dormitories.

Undisciplined behavior is often carried out by students who are in the adolescent phase. According to Erickson (in Santrock, 2003), adolescents are included in the stage of identity development and identity confusion. At this stage the adolescent explores his or her roles in a healthy way and arrives at a positive path to follow, hence a positive identity is achieved. In the period of development, adolescents experience a challenging period (trozalter) which is marked by striking changes in themselves, both physical and psychological aspects, causing emotional reactions and radical behavior. In addition, the adolescent phase 
always has a tendency to fight against authority. Therefore, there are still many students who often do not obey the existing rules.

Senior High School L which is located in the Depok area is one of the schools that requires students at the high school level to live in dormitories. In this school dormitory, there are various regulations that regulate the residents of the dormitory quite strictly, for example, they are not allowed to bring communication devices, are not allowed to use laptops in the dormitory unless they have written permission, and are required to attend congregational prayers in the school mosque.

Many efforts have been made by the school so that its students can obey existing regulations, for example by always punishing students who violate them. In addition, the school also cooperates with parents to hold monthly meetings to discuss their child's development. However, this effort has not been optimally successful due to different backgrounds or living environments, parental support and students' personality factors for the applicable rules and regulations.

This condition was complained by the supervisor of the SMA L dormitory. The indiscipline of students who violated the rules could disturb other students who did not violate the rules. For example, when it was forbidden to use laptops in the dormitory, some students continued to use laptops in the dormitory and finally the regulation was changed to not being allowed to bring laptops from home. This can be detrimental to other students who do not violate it. These students are also not allowed to bring laptops from home.

According to Lemhanas (Wahyu, 2011) discipline is obedience to respect and implement a system that requires people to submit to decisions, orders or regulations imposed for themselves. Another opinion from Tu'u (in Wahyu, 2011) formulates that discipline is an effort to follow and obey applicable rules, values, and laws, which arise because of self-awareness that obedience is useful for his good and success. Meanwhile, Semiawan's opinion (in Wahyu, 2011) defines that discipline can be broadly interpreted as a kind of influence designed to help children to be able to face the demands of the environment.

Based on some of the understandings mentioned above, it can be understood that discipline is an attitude of obedience and obedience of individuals/groups to a predetermined rule and if they do not comply, there will be sanctions given. Within the discipline itself, there are several aspects that need to be developed, so that we can become individuals who have good discipline.

The following are several factors that can affect a person's discipline, namely:

a. The same discipline used by parents and teachers. If parents and teachers feel that their parents have succeeded in educating their sons and daughters well, then parents will apply the same way of raising their children. If parents feel that their way is wrong, then usually parents will switch to using the opposite way with the previous way.

b. Adjustment in a manner approved by group members. Inexperienced parents and teachers are usually more influenced by their group members in the best way than by their own convictions.

c. Education to become parents and teachers. Parents who have received courses in parenting and understand more about their children and the needs of their children, tend to use democratic parenting compared to parents who do not understand their children.

According to Bahri (in Wahyu, 2011) there are three aspects of discipline, namely as follows:

a. Mental attitude which is an obedient and orderly attitude as a result or development and practice of mind control and character control.

b. A good understanding of the system of rules of behavior, this understanding fosters or awareness to understand discipline as a rule that guides behavior.

c. Attitudes and behavior that naturally shows the sincerity of the heart to obey everything carefully. 


\section{RESEARCH METHOD}

In this study, the sample involved was 10 female students with an age range of 16-18 years. The assessments used to determine the training need analysis on the sample are observation and focus group interviews. The intervention is in the form of self-control training, this aims to increase self-control, especially with regard to student discipline so that they can better appreciate the existing rules. Furthermore, the pretest and post-test on the self-control scale were analyzed using the t-test or the different test on the SPSS. The aim is to find out how the difference in the level of self-control of the subject before and after being given the intervention.

\section{RESULT}

The following are the results of the pre-test and post-test that have been given to 10 students which are summarized in the graphic form below:

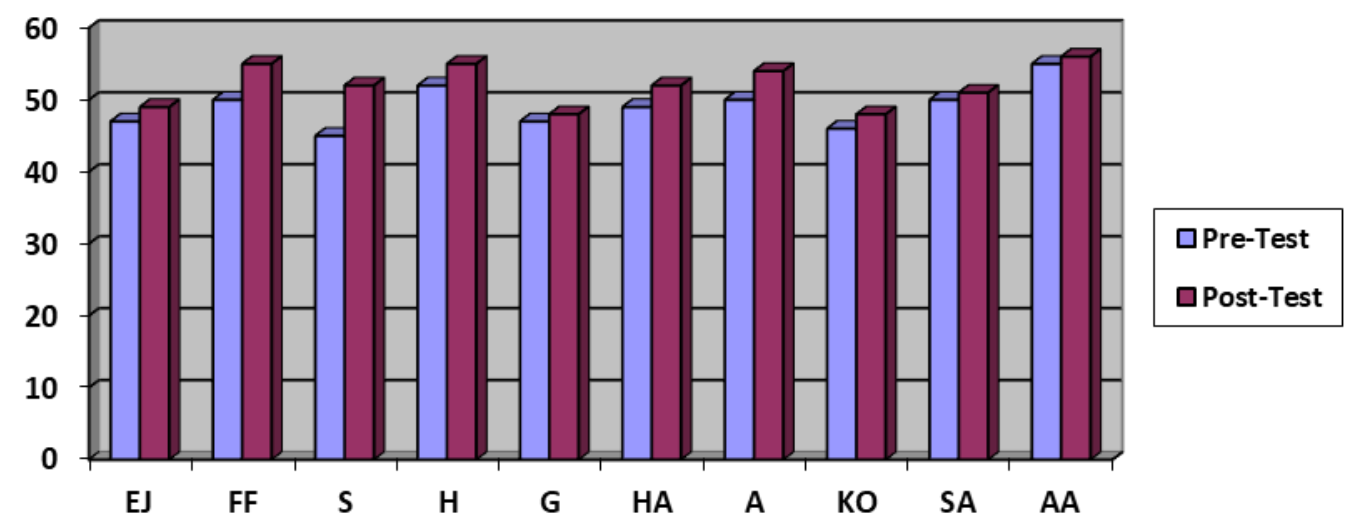

Based on calculations using SPSS with t-test, the results obtained with a t-value of -4.657 and a sig (2-tailed) value of $0.001(<0.01)$. Therefore, it can be concluded that of the 10 members of the boarding school community who participated in the training, all of these members experienced an increase in selfcontrol. This can be seen from the increasing number in the diagram above.

\section{DISCUSSION}

Based on the results of the assessment that has been carried out, it shows that community members experience problems with lack of self-control which causes students to become less disciplined. Coupled with strict regulations, students are bored and bored if they always have to follow them and also some students still do not understand what the meaning and values of the discipline itself are. Based on the assessment, self-control training was conducted to improve students' discipline.

Based on the results of the learning evaluation, obtained a t-test of $0.001(<0.01)$ which indicates that there is a very significant increase in self-control, especially discipline in the members of the boarding community at school L. From the behavioral evaluation conducted by the companion, the results show that there are behavior change from before intervention and after intervention. In addition, the evaluation of the reactions showed that this training had been carried out well.

Based on the results of the evaluation that has been described above, it shows that almost all of the student group members experience changes in behavior for the better. The results in the recapitulation table of rule violations in the dormitory show a positive change before and after the intervention activities. 
Problems that often arise are caused by the strict regulations given by the school which incriminate the students, so that students feel uncomfortable and most of them commit violations. Social factors and internal factors of students in this case are also a problem, this age of adolescence is an age where it is strongly influenced by friends and their environment. These students are in a youth environment. Age that tends to be too young, makes teenagers lack good self-control. Anything related to him, such as controlling emotions, controlling not to go along with friends, controlling himself to do things that violate norms, etc., is very difficult for individuals to control at a young age. This is in line with the theory of factors that affect self-control proposed by Calhoun and Acocella (1990), namely the older a person gets, the better his ability to control himself will be.

The success of this intervention activity is in accordance with previous research conducted by Martina and Syarifudin (2014) which explained that several things that support the success of a training are:

a.Delivery of clear material so that trainees can understand and absorb all the material provided during the training and can apply it in their daily lives.

b.There is an evaluation process after the training activities are carried out, which aims to find out how much influence the training has on changing the behavior of the trainees.

c. The ability of the trainees to understand the material presented.

d.The method or method used to convey the material.

The success of this intervention activity was also supported by the group members themselves. The students who took part in this intervention felt that they needed this intervention to better understand what self-control and discipline are, so that the violations they committed could be reduced or eliminated. They also feel that their behavior is quite disturbing, so they are motivated to make changes. In addition, giving rewards or prizes also increases the motivation of group members to comply with the rules that have been set.

All members feel that this self-control training, apart from being useful in improving discipline, is also very useful for their daily activities. This training can be said to be successful because the material is prepared in a simple way so that students understand and can apply it. Apart from the material aspect, supporting facilities such as room and time provided by the school can be used to provide training as well as supporting factors for the success of intervention activities. The main factor for the success of this training was the support and cooperation from the school which received this training well.

\section{SUMMARY}

Based on the results of the assessment that has been carried out, it can be concluded that the problems experienced by group members are related to disciplinary behavior. The group members have a tendency to behave inconsistently with the rules set by the school, violate the rules, and be undisciplined in their daily lives in the dormitory. These problems can be overcome by conducting training to increase self-control which aims to improve self-control abilities, especially in disciplinary behavior for students. The activity was carried out in four sessions and went well.

Based on the results of the intervention that has been carried out, it is found that almost every student who participates in this intervention activity, experiences changes in behavior in terms of discipline. Group members have been able and aware to control themselves to suppress or reduce the emergence of undisciplined behavior. 


\section{References}

Afiati, N. S. (2018). Kualitas kehidupan sekolah dan disiplin pada santri asrama pondok pesantren (quality of school life and discipline on islamic boarding school students). InSight Jurnal Ilmiah Psikologi, 20(1), ISSN: 1693-2552. DOI:10.26486/psikologi.v20i1.630

Fajaryanti Rosalina Maria. 2016. Skripsi: Hubungan Kedisiplinan dengan Prestasi Belajar Siswa di SMP Maria Immaculata Yogyakarta. Yogyakarta: Universitas Sanata Dharma

Martina, S., \& Syarifuddin, D. (2014). Pengaruh pelatihan dan pengembangan terhadap motivasi dampaknya terhadap prestasi kerja karyawan di lokawisata Barurraden. Jurnal Pariwisata, 1(1). DOI: https://doi.org/10.31294/par.v1il.186

Rukmana, A. \& Suryana, A. (2006). Pengelolaan kelas. Bandung : UPI Press

Syaodih, N. (2004). Landasan psikologi proses pendidikan. Bandung : PT Remaja Rosdakarya.

Singh, J.K., \& Jain, M. (2013). A study of employees' job satisfaction and its impact on their performance. Journal of Indian Research. 1(4), 105-111

Suparjati. (2010). Tata usaha dan kearsipan. Yogyakarta: Kanisius.

Wibowo, I., Pelupessy, D. C., \& Narhetali, E. (2013). Psikologi komunitas. Depok: LPSP3 UI. 